\title{
Giving Girls a Shot: An Examination of Mandatory Vaccination Legislation
}

\author{
Alesha E. Doan and Kellee Kirkpatrick
}

On June 8, 2006, the Food and Drug Administration approved Merck \& Co.'s vaccine Gardasil, which protects women from the human papillomavirus (HPV). Twenty-four states began entertaining initiatives that would make the vaccine mandatory for all fifth-and sixth-grade girls in public schools. However, as the vaccine gained traction in the media, the dominant issue frame put forth by Merck $\mathcal{E}$ Co. was undermined by several competing morality concerns raised by citizens in newspaper opinion pieces. Using an analysis of selected media coverage and a logit analysis modeling the influence of competing morality, economic, and public-health determinants on states' decision making, we investigate the ascent of issue salience surrounding the HPV vaccine, and the policy consideration process. The results from the analysis indicate that citizen-initiated opposition increased the salience of the topic and changed the issue framing in which the mandatory vaccine legislation was being considered. State policy consideration was influenced by a mix of morality and public-health determinants. Moreover, Merck's attempts to influence state policy failed to increase the likelihood of policy consideration.

KEY WORDS: HPV vaccine, mandatory vaccination legislation, morality policy, morality politics, healthcare policy

\section{Introduction}

Political responsiveness to contentious morality policies at the subnational level is often high. The task of achieving congruence between policy positions and citizen preferences is made easier for political elites because of the clear lines typically drawn between supporters and opponents. But responsiveness to morality policies is not guaranteed. It is largely conditioned by other factors, such as the degree of salience surrounding the particular policy or whether the issue intersects with nonmorality interests, namely economic ones (Haider-Markel \& Meier, 1996; Lax \& Phillips, 2009; Mooney \& Lee, 2000; Sharp, 2005; Stabile, 2007). However, the expectations are less clear for policies that have atypical constituencies of support, morality concerns, or potentially far-reaching public-health benefits, or contain a combination of economic interests.

Advances in the biomedical industry have been a financial boon to many private industries because they hold the potential to cure and treat a range of health problems that have affected millions of people. Rather than being universally embraced, 
some of these advances have uncomfortably intersected with morality concerns, catapulting them into the political arena. Because of its inherent link to the sexual behaviors of young people, the human papillomavirus (HPV) vaccine is such a case.

On June 8, 2006, the Food and Drug Administration (FDA) gave its seal of approval to the HPV vaccine Gardasil, which can potentially prevent nearly all cervical cancers (World Health Organization, 2006). Merck \& Co., producer of the vaccine, heavily engaged in behind-the-scenes lobbying of state legislatures, encouraging them to adopt policies that would increase the demand for the vaccine while simultaneously launching a proactive education campaign directed at potential opponents to the policies. In the absence of much public discourse, Merck's efforts initially paid off. A mere three months after FDA approval was granted for the vaccine, Michigan became the first state to introduce legislation in September 2006 (National Conference of State Legislatures [NCSL], 2008). Many other states quickly followed suit, entertaining initiatives to make the vaccine compulsory for young girls.

Despite many states' initial enthusiasm, legislation pertaining to the HPV vaccine quickly disappeared. In particular, the proposed bill for mandatory vaccinations for school-age young women disappeared from states' agendas as quickly as it had arrived. In this case, economic, morality, and public-health issue frames appear to have competed against each other in the proposed legislation. The political aftermath resulting from these competing issue frames was reignited during the GOP primary debates in 2011. Republican presidential hopeful Governor Rick Perry was heavily criticized for signing an executive order in February 2007 making the HPV vaccine mandatory for school-aged girls in Texas. Republican candidates pounced on Governor Perry, with Senator Rick Santorum leading the charge. He questioned Governor Perry's priorities, saying, "Gov. Perry's out there and claiming about states' rights and states' rights. How about parental rights being more important that states' rights?" (Isikoff, 2011, para. 14).

Using a theoretical framework drawn from morality politics literature, we investigate the changing parameters of the issue salience surrounding the HPV mandatory vaccine legislation, as well as examine the determinants that influenced a state's consideration of the legislation. We argue that as the mandatory vaccine measure gained traction, the initial public-health framing of the issue became unstable. The legislation became increasingly salient and linked to several other issue frames, including issues of morality. The heightened salience of the issue, combined with inconsistent constituencies of support, provided conflicting decision cues for states.

A review of selected literature from morality politics, focusing on the theoretical expectations derived from prior work, and a brief history of the ascent of HPV legislation to the political agenda will be presented. To contextualize the environment surrounding this policy, we examine a select number of newspapers to gauge the salience of the issue. A logit analysis of the determinants of states' likelihood of considering mandatory vaccine legislation follows, with the goal of unraveling the relative influence of morality factors, economic interests, and public-health concerns on state legislative activity. The results of the analysis suggest that changes in the salience of the issue occurred, and these changes were initiated by individuals 
writing in to newspapers, rather than by organized interests. In turn, states' policy decisions were influenced by an unusual mix of public-health needs and morality factors, including an unusual constituency that was supportive of the legislation. Departing from theoretical expectations, economic determinants had a minor role in states' decisions. The implications of these findings for morality politics and emerging biomedical policies are also discussed.

\section{Morality Politics}

Morality policies refers to a unique category of public policy that is aimed at regulating behavior through laws and is typically defined by the participation of at least one group that relies on moral arguments to advocate for, or against, the particular policy (Haider-Markel \& Meier, 1996; Tatalovich \& Daynes, 2011). Morality policies have been grouped together based on shared traits commonly associated with these conflicts, such as intractability, simplicity, and salience. These characteristics have led scholars to contend that the scope of conflict surrounding a morality policy can easily be expanded, carrying the potential to generate higher levels of citizen participation (Meier, 1994; Mooney, 2001).

Many morality politics battles are waged at the state level, where theoretically a closer congruency can be achieved between citizen preferences and policy (Mooney, 2001). Political responsiveness to morality disputes is expected to be heightened because constituents can easily become involved in them (Haider-Markel \& Meier, 1996; Mooney \& Lee, 1995). However, several studies have indicated that morality conflicts are not created equally, and political responsiveness to these issues is more nuanced than originally suspected. While "culture war" issues are often popularly portrayed as conflicts between individuals who hold extreme ideological positions on the left and the right, research has indicated that public opinion, and its effects on many morality policies, is contextual (Haider-Markel \& Kaufman, 2006; Mooney \& Lee, 2000). The electorate often holds ambivalent attitudes toward controversial topics, depending on which specific issue is under consideration (Craig, Martinez, Kane, \& Gainous, 2005).

At times, these issues resonate with the public, and at other times, they fail to inspire an equivalent level of interest. Mooney and Schuldt's (2008) study of morality issues found little support indicating that morality politics are inherently salient. Rather, the results of their survey indicated that morality issues were no more salient to respondents-and on some issues even less-than nonmorality issues. Even on highly contentious issues such as gay and lesbian rights, political responsiveness is conditioned upon the relative salience of the particular policy being considered (Lax \& Phillips, 2009). ${ }^{1}$ When a policy is highly salient to the electorate, political responsiveness and congruence with mass opinion is also high. Lower issue salience translates into less responsiveness and higher incongruence.

Studies have also found that politicians are more responsive to contentious morality issues, particularly when public sentiment toward the issue is divisive and there are clear supporters and opponents of the issue (Camobreco \& Barnello, 2008; Mooney \& Lee, 2000; Sharp, 2002). Meier (1999) distinguishes morality policies that 
are sin issues from those that are redistributive. His delineation between the two types of morality issues elucidates how the expansion of conflict surrounding a morality issue can take shape. A sin issue has only one legitimate moral perspective, and little variation exists among citizens' attitudes toward it. In contrast, a redistributive morality policy has competing perspectives, and at least one perspective is rooted in moral opposition to the issue.

However, the possibility of transforming a sin policy into a redistributive policy exists when political actors or citizens change the way an issue is framed (Meier, 1999). Introducing competing issue frames becomes essential to changing the parameters of the debate and transforming an issue from a sin to a redistributive policy. This process can work in the reverse manner as well; a nonmorality issue can be recast as a morality conflict when the framing changes (Meier, 1999). In the absence of public opinion measures, Calfano's (2010) research suggests that politicians may rely on the "political brand" associated with a particular group as a proxy measure for public opinion to help translate constituents' preferences into policy preferences. He found evidence that representatives relied on the pro-life reputation of white Evangelicals and Catholics to inform their position on state abortion policy.

Political parties and elites are often attracted to morality issues because they present an "easy way to build a political reputation or stereotype one's opponents" and garner electoral support from the coalitions mobilized around the issue (Haider-Markel \& Meier, 1996, p. 334). While individual politicians may benefit from involvement in morality disputes, they typically adhere to their political parties' positions on specific morality issues (Haider-Markel, 2001). As ideological polarization between the parties has widened, this pattern has become even more pronounced (Layman, Carsey, Green, Herrera, \& Cooperman, 2010).

However, research has indicated that politicians' responsiveness to morality issues is also dampened by the stakeholders involved in the conflict. In her study of five disparate morality issues, Sharp $(2002,2005)$ found evidence that cities responded differently to these issues based on whether economic stakeholders were active participants in the conflict. "Economic considerations supplant the subcultural explanations only when industry forces have clear-cut material stakes in the issue or when an issue has strong implications for the community's economic development" (Sharp, 2005, p. 197). Consonant with these findings at the local level, Stabile (2007) found a similar pattern at the state level concerning cloning laws. Although both morality and political economy determinants were related to a state's policy, the presence of a strong biotechnology industry resulted in more permissive cloning policies. Stabile's findings, in conjunction with other studies, provide evidence suggesting that organized economic interests generally displace morality interests in the policymaking process.

The extant morality politics literature yields several testable hypotheses regarding morality policymaking in the states. Issue salience is expected to stimulate political responsiveness to HPV legislation. Under conditions of heightened salience, the literature also leads to the expectation that policy decisions about HPV legislation will be influenced by political elites' desire to be responsive to the preferences of constituents' and organized interests as well as adhere to their respective political 
parties' position on the policy. Finally, the participation of economic stakeholders is expected to mediate morality factors and be positively related to HPV legislation.

The mandatory HPV vaccination legislation is a case that encapsulates several aspects of morality policy. The influence of issue salience, economic stakeholders, and morality considerations on policymaking has been discretely studied. However, unlike most morality policies, including those that have economic stakeholders, HPV legislation is also directed at enhancing the provision of a significant publichealth benefit. In this situation, the theoretical expectations of morality politics are not as clear because of the confounding interplay between several competing interests. Tracing the origin of HPV legislation will help illuminate its ascent to the political agenda and transformation from being framed as a public-health issue into a salient morality issue.

\section{The Politics of HPV}

In 2004, Merck \& Co. was forced to pull its arthritis pain medication, Vioxx, off the market after it was linked to an increased risk of heart attacks and strokes (Smith, 2006). Not only did Merck lose its "cash cow," which pulled in approximately $\$ 2.5$ billion each year, the incident caused the company's stock value to take a dive, dropping nearly 27 percent (Rubin, 2004). Analysts estimate that in the end, Merck could see between $\$ 30$ and $\$ 50$ billion in costs from its Vioxx problem (Smith, 2006). The loss of Vioxx was not Merck's only setback. In June 2006, the company's patent expired for its "top-selling drug, the cholesterol-cutting Zocor," which brought in approximately $\$ 4.4$ billion in sales each year (Smith, 2006, para. 13).

On the heels of these setbacks, Merck received a boost; the FDA approved its latest product, Gardasil, on June 8, 2006. Gardasil is a vaccine that protects women from HPV, a sexually transmitted infection that has been identified as the cause of nearly all cervical cancers (World Health Organization, 2006). HPV is the most prevalent sexually transmitted infection in the United States. Estimates project the mortality rate of cervical cancer in the United States ranges between 3,700 and 4,000 per year (Centers for Disease Control and Prevention, 2011; NCSL, 2008).

In addition to mortality, approximately 26,000 women are affected by cervical cancer each year. This number is continuously growing, with roughly 12,000 more women diagnosed each year. With the annual growth in the number of women in the United States affected by HPV and cervical cancer, Merck was positioned to reap gains on two fronts. ${ }^{2}$ Gardasil is a preventative cure for HPV and the cancers associated with HPV infections, and the widespread scope of this public-health problem translates into considerable profits for the company.

\section{Merck's Lobbying Campaign}

Before Gardasil received FDA approval, Merck began campaigning for mandatory HPV vaccination (Wilson, 2007). Its marketing strategy included a combination of aggressively lobbying state legislatures and increasing campaign contributions to targeted political elites. In particular, Merck found strong support in Women in 
Government, a national, bipartisan organization of state legislators that serves as an educational and networking resource for female policymakers (Drug Week, 2006, para. 6).

Merck's lobbying efforts also included a preemptive attempt to dilute the concerns of opponents. While the Gardasil vaccine is a significant advancement for women's health, it treats a disease that is sexually transmitted. Consequently, a policy designed to avoid the negative consequences of sexual behavior easily lends itself to opposition from groups that prescribe abstinence until marriage as the most reliable and morally responsible way to avoid the negative consequences that can result from sexual activity. Many in the conservative community perceive childhood immunization against HPV akin to their views about educating minors about contraception, "encouragement or at least unspoken approval of premarital sex" (Beil, 2006, p. 1A).

Conservative groups, who are well established and organized, presented a viable threat to Merck's legislative endeavors. Attempting to assuage these groups' concerns, Merck arranged meetings with the leaders of the more prominent conservative organizations that advocate for abstinence-only education, such as the Family Research Council, Focus on the Family, and Physician's Consortium (Beil, 2006). Merck's educational outreach appeared to have resulted in some success. Several notable members of the conservative community, like Dr. Gene Rudd of Christian Medical \& Dental Associations, publicly concluded that an HPV vaccine does not undermine abstinence-only education.

Although many conservative leaders' beliefs about the HPV vaccine became more positive, others balked at the idea of making the vaccine mandatory for school admission. While Merck's outreach softened opposition from the more influential groups, it did not completely quell all of the concerns related to the vaccine, particularly those related to adolescent sexuality.

\section{HPV Legislation}

The lobbying efforts of Merck materialized in state legislatures. Three different types of legislation were introduced in a significant number of states. One type of policy required disseminating information to girls entering fifth and sixth grade (and their parents) about HPV, its link to cervical cancer, and the benefits of receiving the HPV vaccination. ${ }^{3}$ Another type of legislation pertained to increasing access to the vaccine by either requiring the vaccination to be covered by Medicaid, state benefits, and/or insurance companies, or by having state funds cover part or all of the vaccination costs. ${ }^{4}$ The final, and most controversial, category of legislation required girls to be vaccinated in order to attend school (NCSL, 2008; Women in Government, 2008).

Despite this initial flurry of legislative activity, negative press concerning Merck's relationship with political elites began to surface, in particular, the company's link to Women in Government. In early 2007, the news media began to cover the connection, reporting that Merck had "funneled money through Women in Government" to lobby state legislators (Associated Press, 2007, para. 7; Gold, 2007). The 
Associated Press also revealed that a prominent executive from the pharmaceutical company's vaccine department held a seat on the business council for Women in Government (Associated Press, 2007).

Other questions regarding the morality and safety of the HPV vaccine were starting to be raised in the media by a diversity of individuals (Gold, 2007; Wilson, 2007, para. 2). Criticism was waged from some public-health officials who were concerned that the pharmaceutical company was motivated by the financial bottom line rather than public health. Larry Gostin, an expert in public-health law from Georgetown University, told National Public Radio reporter Brenda Wilson that "this, what seems to me to be a steamroller effort, makes me very uncomfortable because it's being pushed so hard by the company itself, which stands to make a lot of money" (Wilson, 2007, para. 4). Gostin's sentiments are not unwarranted, as experts predict that Gardasil sales could net Merck between \$1.6 and \$2 billion dollars annually (Smith, 2006). Making the vaccine mandatory, which requires injecting three doses per individual at a price of approximately $\$ 360$ per dose, could increase those projected profits (Centers for Disease Control and Prevention, 2011).

With the negative press and growing scrutiny of vaccination mandates, Merck announced that it planned to abandon its pursuit of this particular legislation at the end of February 2007. Mary Elizabeth Blake, public affairs official, released a statement saying that "We do not want any misperception about Merck's role to distract from the ultimate goal of fighting cervical cancer, so Merck has re-evaluated its approach at the state level and we will not lobby for school requirements for Gardasil" (Childs, 2007, para. 9). Company spokesperson Richard Haupt did say, however, that Merck would continue to promote education about the vaccine through "legislators, health departments and coalition groups in various states" (Reuters, 2007, para. 8). Following Merck's announcement, most state legislatures that had initially considered bills making the vaccine mandatory withdrew the legislation, voted it down, or let it die in committee. Virginia was the only state that passed a compulsory mandate, but the Virginia legislature subsequently introduced a bill in 2008 that delayed the requirement of the HPV vaccination (NCSL, 2008).

Despite Merck's original legislative successes, the rapid demise of the mandatory vaccination policy suggests that the political environment of the issue became unstable. Anecdotally, an unlikely patchwork of individuals, including vaccine skeptics, conservatives, and journalists, started to criticize the vaccine as well as uncover the ethically questionable relationship between Merck and several political elites. But the catalyst for generating issue salience around the mandatory vaccination is not clear, particularly given Merck's two-pronged lobbying strategy that targeted both supporters and likely opponents to the legislation.

However, two studies examining the HPV vaccine and public opinion implicate issue framing as the key factor for understanding public support and opposition of the vaccine. Shortly following FDA approval of the HPV vaccine in June 2006, the Center for Excellence in Cancer Communication Research (CECCR) conducted an opinion poll on a representative sample of 635 U.S. adults regarding their opinion about obtaining the HPV vaccine. Respondents were randomly assigned to three different descriptions of the HPV vaccine, which influenced their likelihood of 
getting the vaccine. When the vaccine description informed respondents that the vaccine protected against cervical cancer, 63 percent of females said they were "very" or "somewhat likely" to obtain the vaccine (CECCR, 2007). The percentage dropped significantly to 43 percent when respondents were informed that the vaccine also protected against a sexually transmitted infection, indicating that respondents were sensitive to the context of the vaccine's description.

CECCR conducted a new opinion poll in 2007 to gauge opinions toward implementing a mandatory HPV vaccine policy; almost half of the adults surveyed were opposed to it (CECCR, 2007). Two years after the mandatory vaccine controversy died down, Gollust, Dempsey, Lantz, Ubel, and Fowler (2010) conducted a representative Internet-based survey between June 19 and July 2, 2009, to determine the impact of issue framing on respondents' opinions toward mandatory HPV vaccination. Respondents were randomly exposed to different hypothetical news briefs about the HPV vaccine. One news brief framed the vaccine in a neutral, uniformly supported health frame, whereas the second news brief framed it in a contentious frame. Only 22.8 percent of respondents who viewed the controversial news brief were supportive of mandatory vaccination compared with 37.3 percent of respondents who viewed the neutral new brief. While these studies indicate that individuals' support for the vaccine was sensitive to hypothetical issue framing, they do not explicitly examine whether changes occurred in the issue framing and salience surrounding the HPV vaccine. However, a closer examination of media coverage provides some insight.

\section{Rising Salience}

To investigate changes in issue salience, which forms the context for states' policy decisions regarding the HPV legislation, an examination of media coverage by four major newspapers was conducted. Using the LexisNexis Academic database, publications including articles and opinion pieces addressing the HPV vaccine were identified for the time period beginning January 1, 2006, and ending April 30, 2007. The start date was chosen to provide a baseline of media attention devoted to the issue prior to the FDA's approval of Gardasil on June 8, 2006, and the end date allows for an examination of media coverage after Merck \& Co. chose to end its state lobbying campaign on February 20, 2007.

Four major news sources were chosen, including The New York Times, the Chicago Sun-Times, The Dallas Morning News, and The Washington Post. These papers were selected for their geographical diversity and, in the case of The New York Times and The Washington Post, for their nationwide audience. The Dallas Morning News was specifically chosen to examine local coverage of the unique handling of the HPV vaccine by Texas Governor Rick Perry and the response of the Texas legislature. ${ }^{5}$ The search was conducted using several iterations of key terms including HPV, Vaccine, and Cervical Cancer. ${ }^{6}$

The content of all media coverage was coded based on the primary issue frame of the story. Articles and opinion pieces were separated in the analysis because a qualitative difference exists between these forms of media coverage. Although the 
Monthly Media Coverage of HPV Vaccine January 2006-April 2007

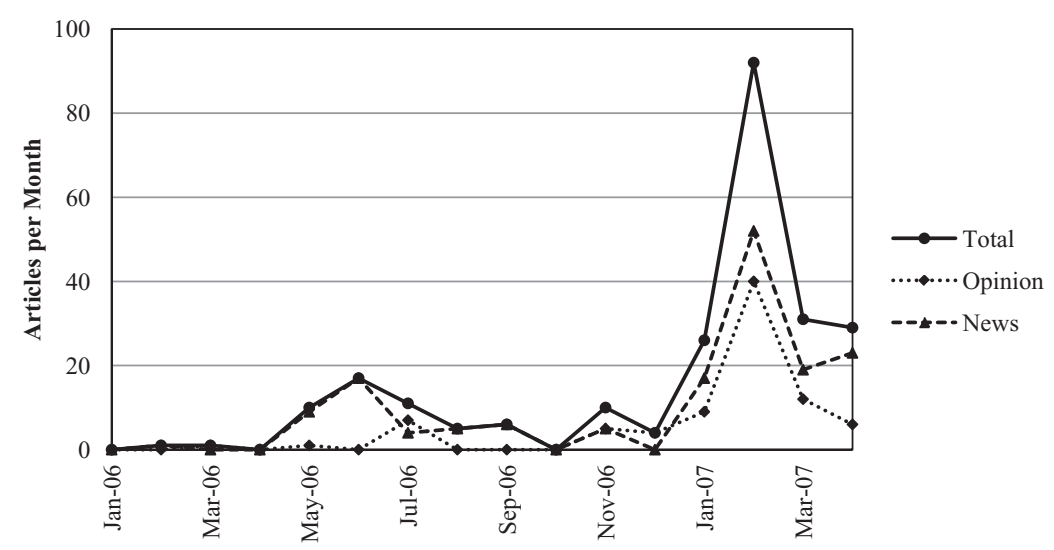

Weekly Media Coverage of HPV Vaccine January 2007-April 2007

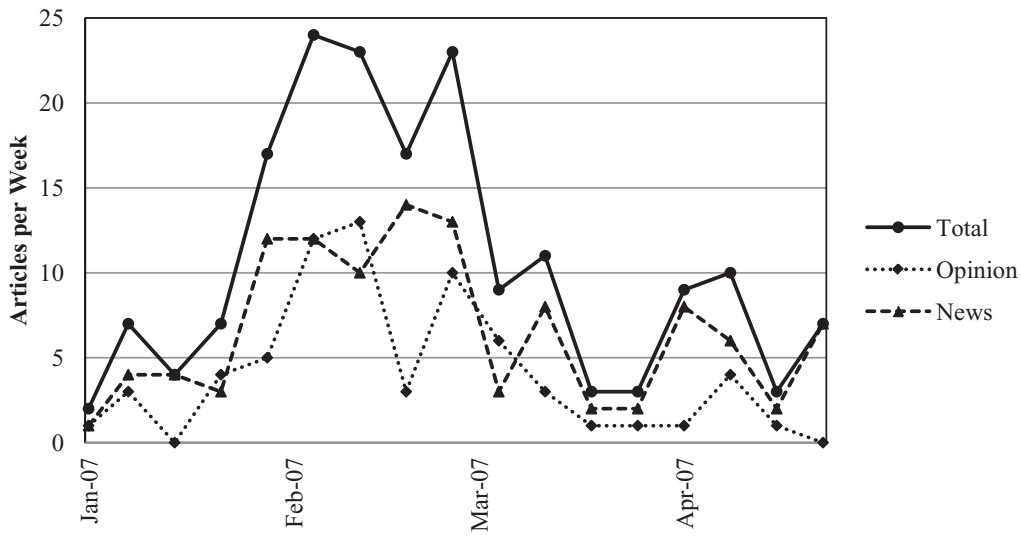

Figure 1. Monthly and Weekly Media Coverage of the HPV Vaccine.

sheer volume of articles and opinion pieces provide an indication of overall issue salience, articles represent a more balanced, journalistic reporting of HPV-related news. Conversely, editorials and opinion pieces represent concerned citizens' opinions on this issue.

Twenty different topics were identified in both articles and opinion pieces. Most of these topics could be categorized into four main issue frames: political, public health, economic, and morality. ${ }^{7}$

Figure 1 contains a graph of all newspaper coverage of HPV-related stories on a monthly basis, delineated between articles and opinion pieces. Two key media peaks are visible. The first rise in coverage spans a three-month time period that begins in May 2006, peaks in June, and remains relatively high in July. This three-month period includes the month leading up to the FDA's approval of Gardasil as well as the month following approval. During this first spike in newspaper coverage of HPV, 
few opinion pieces were written on the topic. The figure also indicates that news accounts of HPV-related stories ramps down considerably for the next five months.

The second and most dramatic spike in media attention begins in January 2007, peaks in February, and remains relatively high until April. This concentrated media peak can be seen in the more detailed weekly plot in Figure 1. During this fourmonth span, articles were reporting about Merck's "funneling of money" to political elites, its ties to specific organizations, and its extensive lobbying efforts. The results indicate that media coverage of Merck's unseemly relationship with key political elites served as the catalyst for creating issue salience, which begot more salience, generating a rapid influx of opinion pieces written by citizens on the topic of HPV.

Within this context, the dominant, positive public-health framing of the issue-improving women's health-started to be challenged by less favorable frames about the vaccine, primarily written in the opinion pieces. Figure 2 displays the changes in issue framing over time in newspaper articles and opinion pieces. The most significant contrast between the articles and opinion pieces pertains to the morality framing of the issue. As newspaper articles began reporting about Merck's behind-the-scenes politicking, citizens began writing many more opinion pieces framed in terms of morality that lambasted the compulsory vaccine legislation's implications for abstinence, promiscuity, and parental rights.

Table 1 presents some general comparisons of the content of the articles and opinion pieces. The general differences found between the framing in articles and opinion pieces suggest that issue salience was developing along two paths. As Table 1 shows, the political frame of the HPV vaccine issue was the most common one used in the news articles, accounting for 51.91 percent of the stories. Articles framing the HPV vaccine as a public-health issue followed in frequency (27.2 percent), while only 4.3 percent and 3.16 percent of the articles framed it in terms of economic or morality issues, respectively.

In stark contrast, a different array of issue frames emerged in the opinion pieces. While coverage of the politics and economics of the HPV vaccine was present, these two frames were minor, only accounting for 15.3 percent and 4.71 percent of opinion pieces, respectively. The most prevalent issue frame in the opinion pieces was morality, accounting for 36.48 percent of them. Opinion pieces in this category questioned the morality of the policy and lamented the dire implications a mandatory vaccine would have on abstinence-only education. Using a morality framing of the issue, these opinion pieces also cast the legislation as an infringement of parental rights. Following in frequency, the second most prevalent frame contained in the opinion pieces was public health (29.41 percent).

The intersection of public health, strong moneyed interests, and morality politics characterizes the context of the HPV vaccine discourse in newspaper articles and opinion pieces. This general survey of selected national media coverage indicates that when the media began reporting about Merck's inappropriate lobbying practices, issue salience quickly surged and the framing of the stories rapidly changed. In a concentrated time period, news articles were augmented by a sizable number of opinion pieces that centered on morality concerns that were notably absent in the initial framing of the news stories. These findings support two theoretical 


\section{Issue Framing of HPV Vaccine \\ in Newspaper Articles}

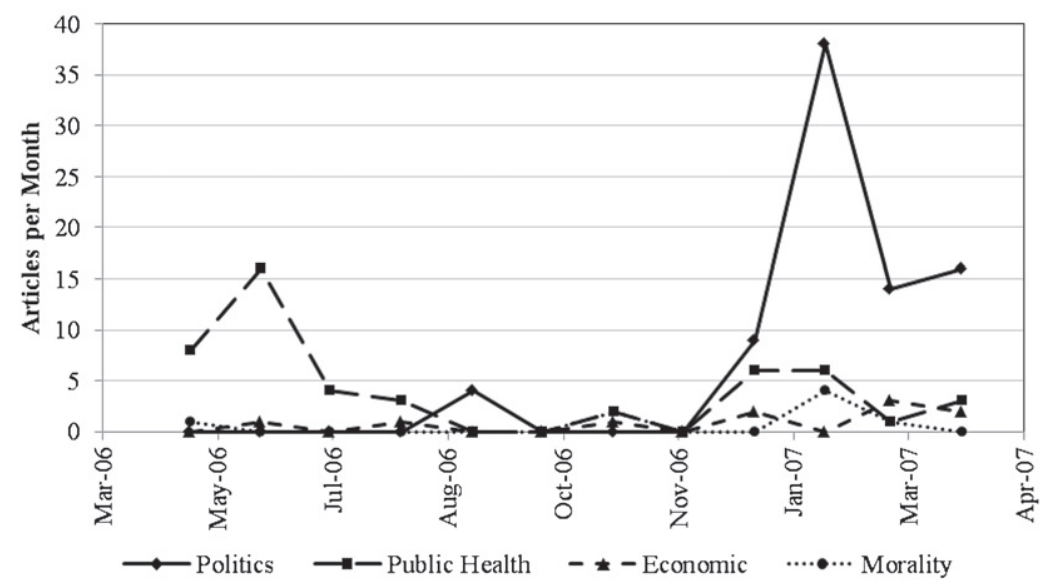

Issue Framing of HPV Vaccine in Opinion Pieces

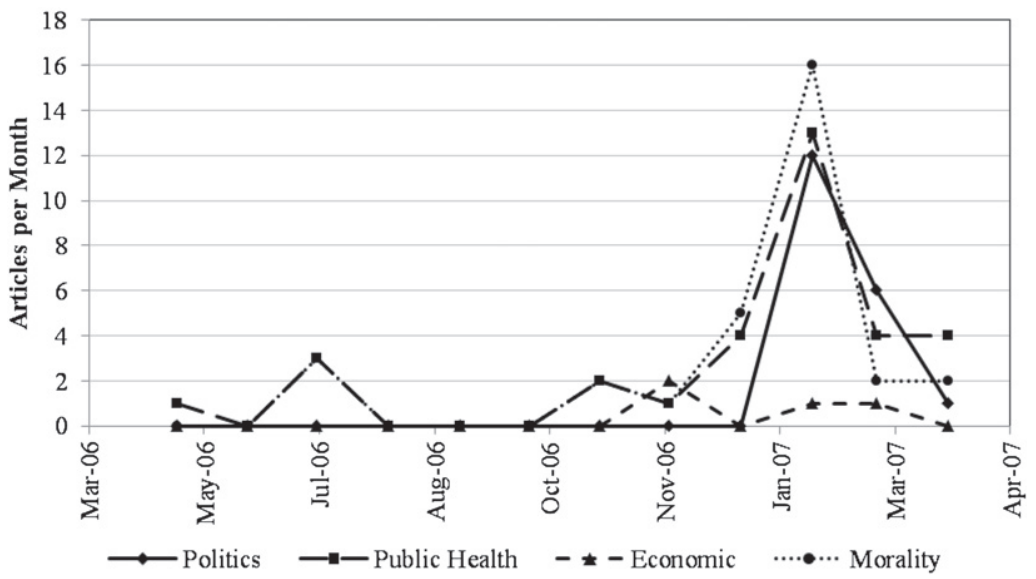

Figure 2. Monthly Issue Framing of HPV Vaccine in Media Coverage.

Table 1. Comparison of Most Prevalent News and Opinion Issue Frames January 1, 2006-April 30, 2007

\begin{tabular}{lclc}
\hline $\begin{array}{l}\text { Articles } \\
\text { Primary Frames }\end{array}$ & Percent of Total & \multicolumn{1}{c}{$\begin{array}{c}\text { Opinion Pieces } \\
\text { Primary Frames }\end{array}$} & Percent of Total \\
\hline Politics & & Morality & $36.48 \%$ \\
Public health & $51.91 \%$ & Public Health & $29.41 \%$ \\
Economic & $27.20 \%$ & Politics & $15.30 \%$ \\
Morality & $4.43 \%$ & Economic & $4.71 \%$ \\
Cumulative percentage & $3.16 \%$ & Cumulative percentage & $\mathbf{8 5 . 9 0 \%}$ \\
Sample size & $\mathbf{8 6 . 7 1 \%}$ & Sample size & $\mathbf{8 5}$
\end{tabular}

Note: Data come from The New York Times, The Washington Post, the Chicago Sun-Times, and The Dallas Morning News. 
expectations from morality politics regarding the conditional nature of salience and ease of mobilization. A one-sided issue can be transformed to a multisided issue if the initial framing is challenged (Meier, 1994). Unlike nonmorality issues, once a morality issue becomes salient, mobilization can be instigated because opposition tends to organize around preexisting, core beliefs (Haider-Markel \& Meier, 1996, p. 334; Mooney, 2001). Underlying value conflict is exposed and "politics is openly redistributive with a focus on key values," rapidly expanding the scope of the conflict (Meier, 1994, p. 685).

In a short period of time it appears that the framing of the HPV vaccine discourse evolved from a public-health frame and became situated in a more contentious morality frame, garnering high levels of public attention and disapproval of the legislation. Within this context, morality determinants are expected to be influential on policy decision making in the states.

\section{Logit Analysis}

The proposed compulsory vaccination legislation provides an opportunity to empirically investigate state legislative decision making when morality, economic, and public-health considerations intersect in a salient environment. Central to the analysis is a state's decision to consider mandatory vaccination legislation, which is coded 1 for a state that considered it and 0 for a state that did not. A cross-sectional logit analysis is employed for the multivariate analysis because of the dichotomous nature of the dependent variable and the short time period in which legislation was introduced. ${ }^{8}$

A total of 36 different bills were introduced in 24 states that would make the vaccine compulsory for school-aged girls. Fourteen of these bills were singleauthored, while the remaining 22 had multiple authors and, in some cases, many sponsors. For instance, the bill introduced in New Mexico, SB 1174, had one author, whereas HB 256, introduced in Vermont, had 112 sponsors. Table 2 contains summary information about the dependent variable, which illustrates the variation that exists in the number of sponsors as well as other key measures. The appendix contains the data sources and coding of the variables.

\section{Morality Determinants}

To assess the impact of morality politics on the HPV legislation, several indicators derived from the morality politics literature are included in the model. Research suggests that incongruence can pose a problem for political elites who have electorally motivated incentives to be responsive to their constituents' opinions on salient morality issues (Mooney \& Lee, 2000). To capture the relative salience of the HPV vaccine issue in the states, a measure of media coverage is included in the model. This variable is measured as the number of articles in major news sources in a state between January 1, 2006, and December 31, 2006. ${ }^{9}$ Media salience is expected to be inversely related to the mandatory legislation. 
Table 2. Legislation, Authors, and Contributions

\begin{tabular}{|c|c|c|c|c|c|c|c|}
\hline State & Bill(s) & Date & Chamber & $\begin{array}{c}\text { Number of } \\
\text { Authors }\end{array}$ & $\begin{array}{c}\text { Accepted } \\
\text { Contributions }\end{array}$ & $\mathrm{R}$ & $\mathrm{D}$ \\
\hline California & AB 16 & 2006 & Assembly & 1 & 0 & 0 & 1 \\
\hline Colorado & SB 07-80 & 2007 & Senate & 13 & 0 & 2 & 11 \\
\hline Connecticut & HB 6977 & 2007 & House & 10 & 0 & 1 & 9 \\
\hline \multirow[t]{2}{*}{ Florida } & SB 660 & 2007 & Senate & 2 & 0 & 2 & 0 \\
\hline & НВ 561 & 2007 & House & 8 & 2 & 3 & $\Gamma$ \\
\hline Georgia & SB 155 & 2007 & Senate & 1 & 1 & 1 & 0 \\
\hline \multirow[t]{2}{*}{ Illinois } & НВ 115 & 2006 & House & 20 & 1 & 0 & 20 \\
\hline & SB 10 & 2007 & Senate & 1 & 0 & 0 & 1 \\
\hline Kansas & HB 2227 & 2007 & House & 37 & 6 & 10 & 27 \\
\hline \multirow[t]{2}{*}{ Kentucky } & HB 143 & 2007 & House & 2 & 1 & 0 & 2 \\
\hline & НВ 345 & 2007 & House & 7 & 3 & 0 & 7 \\
\hline Maine & HP 330 & 2007 & House & 2 & 0 & 0 & 2 \\
\hline Maryland & SB 54 & 2007 & Senate & 21 & 1 & 1 & 20 \\
\hline Massachusetts & SB 102 & 2007 & Senate & 1 & 0 & 0 & 1 \\
\hline \multirow[t]{3}{*}{ Michigan } & HB 4164 & 2007 & House & 22 & 0 & 0 & 22 \\
\hline & HB 4104 & 2007 & House & 5 & 0 & 0 & 5 \\
\hline & HB 5171 & 2007 & House & 9 & 0 & 1 & 8 \\
\hline \multirow[t]{2}{*}{ Minnesota } & НВ 530 & 2007 & House & 4 & 0 & 1 & 3 \\
\hline & SF 243 & 2007 & Senate & 1 & 0 & 0 & 1 \\
\hline Mississippi & НВ 895 & 2007 & House & 12 & 0 & 2 & 10 \\
\hline \multirow{2}{*}{ Missouri } & НВ 902 & 2007 & House & 1 & 1 & 0 & 1 \\
\hline & SB 514 & 2007 & Senate & 1 & 0 & 0 & 1 \\
\hline New Mexico & SB 1174 & 2007 & Senate & 1 & 0 & 1 & 0 \\
\hline \multirow[t]{2}{*}{ New York } & AB 5810 & 2007 & Assembly & 32 & 8 & 4 & 28 \\
\hline & SB 4394 & 2007 & Senate & 1 & 1 & 1 & 0 \\
\hline Ohio & HB 81 & 2007 & House & 11 & 3 & 2 & 9 \\
\hline Oklahoma & SB 487 & 2007 & Senate & 1 & 0 & 0 & 1 \\
\hline South Carolina & HB 3136 & 2006 & House & 5 & 3 & 19 & 33 \\
\hline \multirow[t]{3}{*}{ Texas } & НВ 215 & 2006 & House & 4 & 1 & 0 & 4 \\
\hline & SB 110 & 2006 & Senate & 1 & 1 & 0 & 1 \\
\hline & Exec. Order & 2007 & Executive & 1 & 1 & 1 & 0 \\
\hline \multirow[t]{2}{*}{ Vermont } & HB 256 & 2007 & House & 112 & 0 & 31 & 75 \\
\hline & SB 139 & 2007 & Senate & 5 & 0 & 1 & 4 \\
\hline \multirow[t]{3}{*}{ Virginia } & SB 1230 & 2007 & Senate & 6 & 0 & 0 & 6 \\
\hline & HB 2035 & 2007 & House & 1 & 0 & 1 & 0 \\
\hline & НВ 1914 & 2007 & House & 1 & 0 & 0 & 1 \\
\hline West Virginia & HB 2835 & 2007 & House & 9 & 1 & 1 & 8 \\
\hline Total & & & & 419 & 35 & 86 & 327 \\
\hline
\end{tabular}

Note: In Vermont, four bill sponsors were identified as "Progressive" and two were identified as "Independent."

R, Republican sponsor of bill; D, Democratic sponsor of bill.

Politicians are also far more likely to be responsive to constituents when there are clear supporters and opponents of the issue (Meier, 1994; Mooney \& Lee, 2000). When measures of public opinion are not available, politicians may rely on the branding associated with particular groups (Calfano, 2010). In morality disputes, where conflict is seated in individuals' belief systems, the influence of religion often reigns high. Both Evangelicals and Catholics have spearheaded opposition to policies that take a secularized view toward sexuality and sexual activity; they have a decisively conservative branding on these issues (Doan \& 
Williams, 2008; Jelen, 2011). The Evangelical and Catholic population per thousand people in a state is expected to be inversely related to consideration of mandatory HPV legislation.

Other prominent organized interests are also expected to influence a state's decision to propose the policy. However, as indicated by the results of the content analysis, morality concerns were raised by individual citizens rather than organized groups. In this case, the likely opponents-established conservative groups-were preemptively lobbied by Merck. Many key conservative organizations that advocate for abstinence-only education were supportive of HPV legislation. These groups publicly concluded that the vaccine did not interfere with the lessons of abstinence education, rendering the political branding associated with these groups as an unclear proxy measure of constituency opinion for policymakers.

To test the influence of this mixed signaling on decision makers, a proxy measure for the strength of the abstinence-only movement in a state is included in the model. Beginning around 2000, abstinence-only groups started to proliferate at the state level through the authorization of federal grants in Title V of the Personal Responsibility and Work Opportunity Reconciliation Act of 1996. Upon receiving Title V funding, state health agencies may allocate the funds to subgrantees, which includes a diversity of groups that focus on services ranging from promoting abstinence-only education in the classroom to promoting it among adolescent social groups (Doan \& Williams, 2008). Without groups to deliver abstinence-only programs, states experience difficulty in spending the funds and may forgo their eligible share of the funding. Therefore, the amount of Title V funding per capita accepted by each state is employed as a proxy measure for the strength of organized abstinence interests in a state. A stronger abstinence presence in a state is expected to be inversely related to mandatory vaccination legislation.

The Planned Parenthood Federation of America (PPFA) is situated on the opposite spectrum, with a clear liberal branding. Operating for over 90 years, PPFA runs approximately 850 health centers throughout the United States (Planned Parenthood Federation of America, 2009). Planned Parenthood also operates the Planned Parenthood Action Fund, which focuses on advocacy and political activity at the state level. PPFA was a vocal advocate for the mandatory legislation and named as a key supporter in media coverage of the issue. The strength of Planned Parenthood is measured by the number of clinics per million population operating in a state, and it is expected to increase the likelihood that a state proposed the mandatory vaccine legislation.

Finally, studies suggest that politicians tend to toe their party's line on morality issues (Haider-Markel, 2001; Layman et al., 2010). The Democratic Party is viewed as "owning" certain political issues, such as those relating to social welfare, whereas the Republican Party "owns" other issues, such as those relating to taxes (Petrocik, Benoit, \& Hansen, 2004), although the mandatory HPV bill had bipartisan support in several states, suggesting this issue was not clearly owned by either party. However, as shown in Table 2, the legislation was sponsored more frequently by Democratic politicians, and the initial public-health framing of the HPV vaccine tends to align with the social welfare issues that are perceived as being "owned" by Democrats. 
Therefore, the percentage of House Democrats in the state legislature is expected to be positively related to the introduction of mandatory vaccine legislation.

\section{Economic Determinants}

When economic stakeholders are involved in morality policies, studies indicate that their interests can trump or moderate the influence of morality determinants on policy decisions (Sharp, 2002; Stabile, 2007). Two indicators of Merck's economic interests in this policy are included in the model. First, Merck and Co. opted to lobby state legislatures and make campaign contributions to political elites. Money is often used to "afford favored access on matters involving direct economic benefits to givers" (Adamany, 1980, p. 596), and Merck stood to gain a large profit from the passage of mandatory vaccination.

Several of the elected officials who had received contributions from Merck had a central role in introducing the legislation in 2006. For example, six politicians sponsored the bill in Texas, and half of them had received contributions from Merck, including the governor, who issued an executive order mandating the vaccine for school-aged girls. Likewise, in Illinois, the bill was introduced in the House in the 2006 legislative session; one of the bill's sponsors had been a beneficiary of Merck contributions.

Although the majority of listed authors in the states did not accept Merck contributions (approximately 9 percent of authors were recipients of contributions), examining states rather than authors paints a different picture. As displayed in Table 2, half of all sponsoring states received Merck contributions, suggesting that money may have exerted some influence in the introductory stage of the legislation. Merck's campaign contributions, measured by the total dollar amount of contributions given to candidates for state offices divided by the number of members of the state legislature, is expected to be positively associated with the legislation.

The number of children ages 5 to 17 is the second indicator included in the model to capture Merck's economic incentive to have this legislation passed in larger potential markets. ${ }^{10}$ A larger target population for the vaccine could indicate a stronger need for a solution to the HPV problem or, alternatively, a larger economic market for Merck. States with a larger vaccine target population are expected to be more likely to propose a mandatory vaccination policy.

\section{Public-Health Determinants}

Finally, competing with morality and economic considerations, the HPV vaccine is a solution for a public-health problem. Policymakers face several substantive issues in their decision to propose mandatory legislation, including a state's needs and capacity. Two measures of public-health needs are modeled in the analysis. Public-health determinants are included as the rates of cervical cancer per hundred thousand women in a state and the number of American Public Health Association (APHA) members per hundred thousand population in a state. States with higher 
cervical cancer rates have a greater public-health motivation for mandating the vaccine. The APHA is the oldest and most diverse organization of public-health professionals in the country. It works closely with its state affiliates in conjunction with state decision makers to craft policies that address disease prevention (APHA, 2012). Both of these public-health variables are expected to be positively associated with consideration of the legislation.

\section{State Determinants}

While the HPV vaccine poses a preventative solution to the transmission of HPV and resultant cases of cervical cancer, political actors may not "perceive that adequate resources exist to pay for what needs to be done" (Rochefort \& Cobb, 1994, 26). If states enact this legislation, the cost of vaccination that was not covered by insurance companies would have to be covered by the state. However, some states do not have the capacity to absorb these potential costs. Uninsured women, measured as a percentage, would pose substantial costs to a state and are therefore expected to be negatively associated with the consideration of mandatory vaccination legislation. African American and Latino women experience a higher incidence rate of cervical cancer as well as a higher mortality rate of cervical cancer, compared with white women (CDC, 2011). They also have a much higher uninsured rate, which would have negative economic implications for a state if mandatory legislation is adopted (Kaiser Foundation, 2010). States with a larger percentage of African American and Latino populations are expected to be inversely related to mandatory legislation.

\section{Results and Discussion}

States' likelihood of proposing mandatory HPV vaccination legislation is displayed in Table 3. The fit statistics suggest that the model reasonably predicts the likelihood of policy proposal. Consistent with the theoretical expectations of morality politics, salience and religion are important factors in these policy disputes. While Planned Parenthood, Catholics, and the partisanship makeup of the House were not significant determinants, media salience, Evangelicals, and the abstinence movement were significant. States that had more media coverage of the vaccine were less likely to propose the legislation. A larger Evangelical population also decreased the likelihood of proposal. However, unlike many morality conflicts, this case had a unique melding of supporters. Contrary to expectation, the results of the analysis indicate that a stronger abstinence movement presence in a state, which carries a strong conservative and Christian-based political branding, was positively and significantly associated with consideration of a mandatory vaccine measure. These findings suggest that mixed signaling may have been occurring among conservative organizations.

Economic determinants were also mixed predictors in the model. Merck campaign contributions were not significantly related to the policy, and was not 
Table 3. Determinants of Mandatory HPV Vaccination

\begin{tabular}{|c|c|c|}
\hline Independent Variables & Coefficients & Marginal Effects \\
\hline \multicolumn{3}{|l|}{ Morality determinants } \\
\hline Planned Parenthood & $\begin{array}{c}0.016 \\
(0.220)\end{array}$ & - \\
\hline Abstinence movement & $\begin{array}{c}0.036^{*} \\
(0.018)\end{array}$ & 0.009 \\
\hline House Democrats & $\begin{array}{c}-0.021 \\
(0.038)\end{array}$ & - \\
\hline Evangelical population & $\begin{array}{r}-0.016^{*} \\
(0.008)\end{array}$ & 0.004 \\
\hline Catholic population & $\begin{array}{c}-0.004 \\
(0.007)\end{array}$ & - \\
\hline Media salience & $\begin{array}{c}-0.137^{*} \\
(0.064)\end{array}$ & 0.034 \\
\hline \multicolumn{3}{|l|}{ Economic determinants } \\
\hline Merck PAC contribution & $\begin{array}{c}-0.002 \\
(0.007)\end{array}$ & - \\
\hline Children ages 5-17 & $\begin{array}{c}0.004^{*} \\
(0.002)\end{array}$ & 0.0009 \\
\hline \multicolumn{3}{|l|}{ Public-health determinants } \\
\hline Cervical cancer & $\begin{array}{c}2.16^{*} \\
(0.888)\end{array}$ & 0.538 \\
\hline Public-health professionals & $\begin{array}{c}0.0003^{*} \\
(0.0001)\end{array}$ & 0.00007 \\
\hline \multicolumn{3}{|l|}{ State determinants } \\
\hline Uninsured women & $\begin{array}{c}-0.525^{*} \\
(0.236)\end{array}$ & 0.060 \\
\hline Black population & $\begin{array}{c}-0.132 \\
(0.097)\end{array}$ & - \\
\hline Latino population & $\begin{array}{c}-0.080 \\
(0.086)\end{array}$ & - \\
\hline Constant & $\begin{array}{r}-10.76 \\
(5.72)\end{array}$ & \\
\hline Log likelihood & -16.803 & \\
\hline Pseudo-R-squared & 0.510 & \\
\hline Chi-squared & $34.30 * *$ & \\
\hline $\mathrm{N}$ & 49 & \\
\hline Likelihood ratio test & $14.12^{*}$ & \\
\hline
\end{tabular}

${ }^{*} p<0.05 ;{ }^{* *} p<0.01$.

Notes: Coefficients are logit coefficients; the parentheses contain standard errors. The dependent variable is measured as 1 for states that proposed mandatory legislation and 0 for states that did not propose mandatory legislation. Marginal effects were estimated following the logit model estimation, with the value of the dependent variable set to "proposed mandatory legislation." Marginal effects for dichotomous variables capture the discrete change from 0 to 1 . The likelihood ratio test indicates that including the set of morality determinants in the model is a statistically significant improvement in model fit.

in the hypothesized direction. However, the target population, children ages 5 to 17, was positively related to the proposed legislation, suggesting that the introduction of mandatory vaccination was more likely in states that had a larger target population market.

The content analysis indicated that the HPV vaccine was initially framed as a public-health good that should be shared with women to prevent future cases of 
cervical cancer. The results from the analysis tend to underscore the role that publichealth considerations had in states' decisions to propose mandatory vaccination legislation. Cervical cancer rates, as well as the size of the public-health professional community, have a positive impact on proposing legislation. These variables indicate that the need for the vaccine and perhaps the vociferous articulation of those needs by public-health professionals were influential in states' policy decisions.

Finally, the percentage of uninsured women was the only significant state determinant in the model; neither the African American nor Latino population was significant. Mandatory vaccination would be costly for a state to provide, particularly for states that have a sizable uninsured population. The inability to pay for a mandatory vaccination, rather than the public-health need for the vaccine, may have steered states' decisions on compulsory vaccination policy. This interpretation is underscored by the inverse relationship between uninsured women and proposed legislation. The likelihood of states proposing the legislation decreases as the percentage of uninsured women increases, indicating that a state's capacity to mandate vaccination is an important determinant in the model.

Table 3 also presents the marginal effects coefficients for the model. Marginal effects coefficients are postestimation calculations that can be compared to determine the relative impact of each variable on the probability of a state proposing mandatory legislation, holding all other variables constant (Long, 1997; Long \& Freese, 2005). As indicated in the table, overall, cervical cancer rate and the percentage of uninsured women are the most influential variables in the model. Morality determinants follow in importance, with media salience exerting the most influence out of this group of variables, followed by the abstinence movement and Evangelical population. Although one economic determinant was statistically significant in the model, the marginal effects coefficient indicates that it was nearly the least influential determinant of proposed legislation. Finally, a likelihood ratio test was performed to analyze whether the set of morality determinants significantly improved model fit. The results ( $p$-value of 0.0284 ) indicate that this set of variables is a statistically significant improvement in model fit.

\section{Conclusion}

When an issue is framed as one-sided, policy consensus typically occurs (Meier, 1994). Merck took great pains to frame mandatory vaccination singularly as a publichealth issue. To this end, it lobbied elected officials, made campaign contributions to individual politicians, and even launched a preemptive "educational campaign" targeted at specific organized groups that ascribe to, and support, conservative policy views on issues related to adolescent sexuality. Prominent national organizations, such as Focus on the Family and the Family Research Council, publicly supported the vaccine "because of their life-saving potential" (Smith, 2006, para. 21), while maintaining their position that the best methods to prevent HPV and cervical cancer are abstinence and monogamy.

These coordinated efforts, along with the newness of the issue, may have initially given Merck an advantage, which comports with other research. Studies have found 
that interest groups can have more of an impact when issues are in their infancy because policymakers may not have formed strong beliefs. Under these circumstances, legislators rely more heavily on information provided from organized interests, including professional expertise, when making their individual decisions (Haider-Markel, 1999). Moneyed interests also tend to fare better in legislative politics when there is low salience and opposition, which has been found in studies of morality policies as well.

However, the results of the content analysis and logit analysis indicate that despite Merck's economic interests in the vaccine and careful framing of the issue, once competing morality issue frames surfaced, the policy environment rapidly destabilized. As hypothesized in the morality politics literature, when the discourse surrounding the HPV vaccine became multisided, the scope of conflict expanded and in a short time frame led to the demise of compulsory legislation (Meier, 1999). The results also suggest that while economic interests may supplant or moderate morality concerns even when issue salience is high (Sharp, 2005; Stabile, 2007), this is not an inevitable outcome. Rather, the implications of the results indicate that it is a conditional outcome based on the level of latent opposition among citizens that-once articulated-dovetails with the manifest interests of organized constituency groups.

The findings of the analyses provide more than evidence of this occurrence; they help reveal the dynamic process of issue metamorphosis from a one-sided issue to a multisided morality conflict. Once stories surfaced in the national media scrutinizing Merck's involvement in the legislation, issue salience started to rise. As national salience was increasing, competing morality issue frames were introduced by citizens writing opinion pieces in newspapers denouncing the immoral aspects and implications of mandatory vaccination legislation. Citizens started to challenge the prevailing issue frame, and a positive feedback scenario ensued that created a bandwagon effect over a relatively brief period of time, turning this previously one-sided issue into a contentious multisided morality issue.

This dynamic process was likely fueled by a disparity between the public-health framing of the issue and many individuals' private assessment of the issue-the government is encroaching on the rights of parents and sending permissive messages about sexuality to adolescents. These particular morality concerns resonated and aligned with the views expressed by key organized groups, namely Evangelicals, who are already influential in state politics (Calfano, 2010).

Public opinion data from 2007 tend to corroborate this disparity; less than half of respondents supported mandatory vaccination (CECCR, 2007). Consequently, the framing dynamic was fragile. Research has indicated that under these conditions, problem definition is sensitive to small changes that can initiate a positive feedback system that is nonlinear and leads to rapid change (Wood \& Doan, 2003). The HPV vaccine quickly became situated between several competing interests, including Merck's desire to profit from the sale of Gardasil, the public-health interest to prevent HPV and cervical cancer, and morality concerns primarily related to fears about increased promiscuity among young girls and an infringement of parental rights. 
In the end, the scope of conflict expanded and the HPV vaccine legislation was subjected to a morality politics dispute where the desire to be responsive to publichealth determinants was overshadowed by the need to be responsive to morality concerns. While this case may appear to be unusual, in the context of the frequent biomedical advances taking place (i.e., stem cell research, cloning, and medical abortions), as well as the new morality framing of old issues (i.e., contraception), it is not. When these scientific advances intersect with underlying morality dimensions, particularly those related to sexuality or sexual activity, they can become subject to scrutiny by citizens who lack medical expertise but who are credentialed to assess morality issues. If individuals' morality objections are supported by organized groups that ascribe to similar positions and are active in the policy arena, this interchange can destabilize an issue and rapidly influence the political process. As science and morality intersect, a layer of contention can be created that would not exist if based on scientific evaluations alone.

\section{Notes}

The authors are listed in alphabetical order.

1. Several studies have also found evidence that elites do more than solely respond to public opinion on contentious morality issues. Rather, elites can play a crucial role in creating, fostering, or stabilizing salient morality issues (Haider-Markel, 1998; Haider-Markel \& Meier, 1996; Mooney \& Lee, 2000).

2. Although Gardasil was marketed at young women, it also protects young men ages 9 to 26 against 90 percent of genital warts cases (Gardasil, 2012).

3. By April 2008, 24 states (Arizona, Colorado, Connecticut, Florida, Hawaii, Illinois, Indiana, Iowa, Kansas, Kentucky, Maine, Michigan, Minnesota, Missouri, Montana, New Jersey, New Mexico, New York, North Carolina, North Dakota, Pennsylvania, Vermont, Virginia, Wisconsin) had proposed this type of legislation, and 11 states (Colorado, Illinois, Indiana, Iowa, Maine, New Jersey, North Carolina, North Dakota, Vermont, Virginia, Wisconsin) had passed it (NCSL, 2008; Women in Government, 2008).

4. As of April 2008, 28 states (Arizona, Arkansas, California, Colorado, Connecticut, Florida, Georgia, Hawaii, Illinois, Iowa, Kentucky, Maine, Massachusetts, Mississippi, Missouri, Nevada, New Hampshire, New Jersey, New Mexico, New York, Ohio, Oregon, Pennsylvania, Rhode Island, Texas, Vermont, Washington, West Virginia) had proposed and 9 states (California, Colorado, Illinois, Maine, Nevada, New Hampshire, New Mexico, Pennsylvania, Texas) had passed this type of legislation (NCSL 2008; Women in Government, 2008).

5. Several news media stories surfaced regarding Governor Perry's unsavory connection to Merck. Not only did Governor Perry accept substantial campaign contributions over his political career from Merck, but his former chief of staff, Mike Toomey, was hired as a prominent Merck lobbyist (Fitzgerald, 2011). The Texas governor had signed an executive order making the HPV vaccine compulsory; in retaliation, the legislature passed a law to override the order. The governor did not veto the override bill (NCSL, 2008).

6. The full list of key search terms includes the following: HPV; Human Papillomavirus; Human Papilloma Virus; Vaccine; Vaccination; Gardasil; Cervical Cancer.

7. Political framing includes discussion of the details of the compulsory vaccination, the Texas case, and the role of Merck in the legislative process. Public-health framing includes information about the vaccine, the effects of the vaccine, the FDA approval process, and the potential health benefits and/or side effects of the vaccine. Economic framing includes the cost of the vaccine and the status of Merck stocks. Morality framing includes discussion of how compulsory legislation relates to parental rights and highlights the link to sexual activity, promiscuity, and abstinence. 
8. California, Illinois, South Carolina, and Texas introduced mandatory vaccination legislation in $2006 ; 20$ other states introduced it in 2007.

9. Media salience was generated from LexisNexis Academic, which catalogs and provides full-text access to more than 2,500 papers in the United States and worldwide. The sources primarily include major nationwide and state news sources and some small-town newspapers.

10. Although Gardasil can be given up to age 26, the vaccine must be administered before a person comes into contact with the HPV virus. By the age of 17, most males and females have had intercourse; therefore, the optimal age to receive the vaccine is during early adolescence (Guttmacher Institute, 2012).

\section{References}

Adamany, David. 1980. "PACs and the Democratic Financing of Politics." Arizona Law Review 22: 569-602. APHA. 2009. American Public Health Association. http:/ /www.apha.org. Accessed August 4, 2009.

—. 2012. "Overview." American Public Health Association. http://www.apha.org/about. Accessed March 8, 2012.

Associated Press. 2007. "Texas Governor Orders Anti-Cancer Vaccine for Schoolgirls." USA Today [Online]. http://www.usatoday.com/news/health/2007-02-02-texas_x.htm?POE=NEWISVA. Accessed April 12, 2008.

Beil, Laura. 2006. "Cervical Cancer Vaccine Endorsed: Merck Quietly Deals with Conservative Fears about Premarital Sex." Dallas Morning Star (May 24): 1A.

Calfano, Brian Robert. 2010. “The Power of Brand: Beyond Interest Group Influence in U.S. State Abortion Politics." State Politics \& Policy Quarterly 10 (3): 227-47.

Camobreco, John, and Michelle A. Barnello. 2008. “Democratic Responsiveness and Policy Shock: The Case of State Abortion Policy." State Politics \& Policy Quarterly 8 (1): 48-65.

CECCR. 2007. "Annenberg Survey Finds Little Support for Mandatory HPV Vaccinations." Center for Excellence in Cancer Communication Research. http://www.upenn.edu/pennnews/news/ annenberg-survey-finds-little-support-mandatory-hpv-vaccinations. Accessed February 29, 2012.

Centers for Disease Control and Prevention. 2004. "National Program of Cancer Registry." http:// apps.nccd.cdc.gov/uscs/. Accessed April 20, 2008.

- 2011. "HPV Vaccine Information for Clinicians: Fact Sheet." http://www.cdc.gov/std/HPV/ STDFact-HPV-vaccine-hcp.htm. Accessed March 5, 2012.

Childs, Dan. 2007. “Drugmaker Backs Off Vaccination Campaign; New Report Reveals Contributions to Texas Governor." ABC News (February 22). http://abcnews.go.com/print?id=2890402. Accessed April 20, 2008.

Craig, Stephen C., Michael D. Martinez, James G. Kane, and Jason Gainous. 2005. “Core Values, Value Conflict, and Citizens' Ambivalence about Gay Rights." Political Research Quarterly 58 (1): 517.

Doan, Alesha E., and Jean C. Williams. 2008. Politics of Virginity: Abstinence in Sex Education. Westport, CT: Praeger Publishers.

Drug Week. 2006. "Women in Government Applauds Federal Advisory Group on Papilloma Virus Vaccine Recommendations." LexisNexis. http://www.lexisnexis.com/hottopics/lnacademic/ Accessed April 21, 2008.

Fitzgerald, Alison. 2011. "Perry's Merck Donations Greater Than Acknowledged During Debate." Bloomberg (September 13). http://www.bloomberg.com/news/2011-09-13/perry-s-merckdonations-greater-than-said.html. Accessed February 26, 2012.

Gardasil. 2012. http:/ /www.gardasil.com. Accessed March 7, 2012.

Gold, Rachel Benson. 2007. “Challenges and Opportunities for U.S. Family Planning Clinics in Providing the HPV Vaccine." Guttmacher Policy Review 10 (3): 8-12. [Online]. http://www.guttmacher.org/ pubs/gpr/10/3/gpr100308.html. Accessed April 24, 2008. 
Gollust, Sarah E., Amanda F. Dempsey, Paula M. Lantz, Peter A. Ubel, and Erika Franklin Fowler. 2010. "Controversy Undermines Support for State Mandates on the Human Papillomavirus Vaccine." Health Affairs 29 (11): 2041-46.

Guttmacher Institute. 2012. "Facts on American Teens' Sexual and Reproductive Health." February. http:/ / www.guttmacher.org/pubs/FB-ATSRH.html. Accessed March 8, 2012.

Haider-Markel, Donald P. 1998. “The Politics of Social Regulatory Policy: State and Federal Hate Crime Policy and Implementation Effort." Political Research Quarterly 51: 69-88.

1999. "Redistributing Values in Congress: Interest Group Influence under Sub-Optimal Conditions." Political Research Quarterly 52 (1): 113-44.

. 2001. "Policy Diffusion as a Geographical Expansion of the Scope of Political Conflict: Same Sex Marriage Bans in the 1990s." State Politics and Policy Quarterly 1 (1): 5-26.

Haider-Markel, Donald P., and Matthew S. Kaufman. 2006. "Public Opinion and Policy Making in the Culture Wars: Is There a Connection between Opinion and State Policy on Gay and Lesbian Issues?" In Public Opinion in State Politics, ed. Jeffrey E. Cohen. Stanford, CA: Stanford University, 163-82.

Haider-Markel, Donald P., and Kenneth J. Meier. 1996. "The Politics of Gay and Lesbian Rights: Expanding the Scope of the Conflict." The Journal of Politics 58 (2): 332-49.

Isikoff, Michael. 2011. "Perry's Merck Link in Spotlight Following Vaccine Order: Gardasil Maker Hired His Former Chief of Staff as a Lobbyist in Austin." MSNBC (September 8). http://www. msnbc.msn.com/id/44442051/ns/politics/t/perrys-merck-link-spotlight-following-vaccine-order. Accessed February 26, 2012.

Jelen, Ted G. 2011. “God and Country: Debating Religion in Public Life." In Moral Controversies in American Politics, eds. Raymond Tatalovich and Byron W. Daynes. New York: M.E. Sharpe, 132-60.

Kaiser Foundation. 2010. "Uninsured Rates for the Nonelderly by Race/Ethnicity, States (2009-2010), U.S." http: / / www.statehealthfacts.org/comparetable.jsp?ind=143\&cat=3. Accessed March 8, 2012.

Lax, Jeffrey R., and Justin H. Phillips. 2009. "Gay Rights in the States: Public Opinion and Policy Responsiveness." American Political Science Review 103 (3): 367-86.

Layman, Geoffrey, Thomas M. Carsey, John C. Green, Richard Herrera, and Rosalyn Cooperman. 2010. "Activists and Conflict Extension in American Party Politics." American Political Science Review 104 (2): 324-46.

Long, J. Scott. 1997. Regression Models for Categorical and Limited Dependent Variables. Thousand Oaks, CA: Sage Publications, Inc.

Long, J. Scott, and Jeremy Freese. 2005. Regression Models for Categorical and Limited Dependent Variables Using Stata. College Station, TX: Stata Press.

Meier, Kenneth J. 1999. “Drugs, Sex, Rock, and Roll: A Theory of Morality Politics." Policy Studies Journal 27 (4): 681-95.

Mooney, Christopher Z. 2001. The Public Clash of Private Values. New York: Chatham House Publishers.

Mooney, Christopher Z., and Mei-Hsien Lee. 1995. “Legislating Morality in the American States: The Case of Pre-Roe Abortion Regulation Reform." American Journal of Political Science 39: 599-627.

—. 2000. "The Influence of Values on Consensus and Contentious Morality Policy: U.S. Death Penalty Reform, 1956-1983." Journal of Politics 62 (1): 223-40.

Mooney, Christopher Z., and Richard G. Schuldt. 2008. “Does Morality Policy Exist? Testing a Basic Assumption." Policy Studies Journal 36 (2): 199-218.

National Conference of State Legislatures (NCSL). 2006. "Legislator Demographics." http://www. ncsl.org/default.aspx?tabid1/414850. Accessed September 23, 2006.

—. 2008. "HPV Vaccine." http:/ / www.ncsl.org/programs/health/HPVvaccine.htm. Accessed March 5, 2008.

National Institute on Money in State Politics. 2008. http:/ /www.followthemoney.org. Accessed May 15, 2008.

Petrocik, John R., William L. Benoit, and Glenn J. Hansen. 2004. "Issue Ownership and Presidential Campaigning, 1952-2000." Political Science Quarterly 118 (4): 599-626. 
Planned Parenthood Federation of America. 2009. “Who We Are.” http:/ / www.plannedparenthood.org/ about-us/who-we-are-4648.htm. Accessed July 16, 2009.

Religious Congregations and Membership Study. 2000. "State File." The Association of Religion Data Archives. http:/ / www.thearda.com/Archive/Files/Descriptions/RCMSST.asp. Accessed August 4, 2010.

Reuters. 2007. "Merck Ending Lobbying for Mandatory Gardasil Vaccine." Reuters (February 21). http:/ / www.reuters.com/articlePrint?articleId=USN2022501520070221. Accessed April 21, 2008.

Rochefort, David A., and Roger W. Cobb. 1994. The Politics of Problem Definition: Shaping the Policy Agenda. Lawrence, KS: University Press of Kansas.

Rubin, Rita. 2004. "Merck Halts Vioxx Sales." USA Today (September 3). http://www.usatoday.com/ money/industries/health/drugs/2004-09-30-vioxx-withdrawn_x.htm. Accessed May 3, 2008.

Sexuality Information and Education Council of the United States. 2007. "A Portrait of Sexuality Education and Abstinence-Only-Until-Marriage Programs in the United States (Fiscal Year 2007 Edition)." http: / / www.siecus.org/index.cfm?fuseaction=Page.viewPage\&pageId=487\&parentID=478. Accessed March 25, 2011.

Sharp, Elaine B. 2002. “Culture, Institutions, and Urban Officials' Responses to Morality Issues." Political Research Quarterly 55 (4): 861-83.

- 2005. Morality Politics in American Cities. Lawrence, KS: University Press of Kansas.

Smith, Aaron. 2006. "Merck's Dance with the Religious Right: Drug Giant Close to Approval for Controversial Anti-Cancer Vaccine for Youngsters." CNNMoney (May 16). http://www.cnnmoney.com. Accessed April 28, 2008.

Stabile, Bonnie. 2007. "Demographic Profile of States with Human Cloning Laws." Politics and the Life Sciences 26 (1): 43-50.

Tatalovich, Raymond, and Byron W. Daynes. 2011. Moral Controversies in American Politics. New York: M. E. Sharpe.

United States Bureau of the Census, Government Division. 2006. "Age and Sex for States and for Puerto Rico: April 1, 2000 to July 1, 2005." http://www.census.gov/popest/states/asrh/SC-EST200502.html. Accessed May 10, 2011.

_. 2010. American Community Surveys: Hispanic or Latino/Not Hispanic or Latino, by Race. http://www.census.gov/govs/state/. Accessed May 15, 2011.

Wilson, Brenda. 2007. "Drugmaker's HPV Vaccine Push Raises Questions." National Public Radio, February 22. http:/ /nl.newsbank.com. Accessed May 3, 2008.

Women in Government. 2008. "The 'State' of Cervical Cancer Prevention in America." http:// www.womeningovernment.org/prevention. Accessed April 17, 2008.

Wood, B. Dan, and Alesha E. Doan. 2003. "The Politics of Problem Definition: A Theory and Application to Sexual Harassment." American Journal of Political Science 47 (4): 640-53.

World Health Organization. 2006. "Preparing for the Introduction of HPV Vaccines: Policy and Programme Guidance for Countries." http://www.who.int/reproductive-health/publications / hpvvaccines/index.html. Accessed April 10, 2008. 


\section{Appendix}

Coding and Sources

\begin{tabular}{|c|c|c|}
\hline Variable & Source & Coding \\
\hline $\begin{array}{l}\text { Proposed mandatory } \\
\text { vaccination legislation }\end{array}$ & $\begin{array}{l}\text { National Conference of State } \\
\text { Legislatures (2008) }\end{array}$ & $\begin{array}{l}0=\text { state did not propose legislation } \\
1=\text { state proposed legislation }\end{array}$ \\
\hline Planned Parenthood & $\begin{array}{l}\text { Planned Parenthood Federation of } \\
\text { America (2009) }\end{array}$ & $\begin{array}{l}\text { Number of Planned Parenthood } \\
\text { clinics in each state per million } \\
\text { population }\end{array}$ \\
\hline $\begin{array}{l}\text { Abstinence } \\
\text { movement }\end{array}$ & $\begin{array}{l}\text { Sexuality Information and Education } \\
\text { Council of the United States (2007) }\end{array}$ & $\begin{array}{l}\text { Amount of Title } \mathrm{V} \text { money granted to } \\
\text { a state for abstinence programs } \\
\text { per capita }\end{array}$ \\
\hline House Democrats & $\begin{array}{l}\text { National Conference of State } \\
\text { Legislatures (2006) }\end{array}$ & $\begin{array}{l}\text { Percentage of Democratic House } \\
\text { representatives in } 2006\end{array}$ \\
\hline $\begin{array}{l}\text { Evangelical } \\
\text { population }\end{array}$ & $\begin{array}{l}\text { Religious Congregations and } \\
\text { Membership Study (2000) }\end{array}$ & $\begin{array}{l}\text { Rates of adherents per thousand } \\
\text { population }\end{array}$ \\
\hline Catholic population & $\begin{array}{l}\text { Religious Congregations and } \\
\text { Membership Study (2000) }\end{array}$ & $\begin{array}{l}\text { Rates of adherents per thousand } \\
\text { population }\end{array}$ \\
\hline Media salience & LexisNexis Academic & $\begin{array}{l}\text { Number of articles in major news } \\
\text { sources in a state between January } \\
1,2006 \text { and December 31, } 2006\end{array}$ \\
\hline $\begin{array}{l}\text { Merck PAC } \\
\text { contribution }\end{array}$ & $\begin{array}{l}\text { National Institute on Money in State } \\
\text { Politics (2008) }\end{array}$ & $\begin{array}{l}\text { Total \$ given to candidates in } 2006 \\
\text { in a state divided by the total } \\
\text { number of state legislators }\end{array}$ \\
\hline Children ages 5-17 & United States Census Bureau (2006) & $\begin{array}{l}\text { Number of children aged } 5 \text { to } 17 \\
\text { years old in } 2005\end{array}$ \\
\hline Cervical cancer & $\begin{array}{c}\text { Centers for Disease Control and } \\
\text { Prevention (2004) National } \\
\text { Program of Cancer Registry }\end{array}$ & Rate per hundred thousand in 2004 \\
\hline $\begin{array}{l}\text { Public-health } \\
\text { professionals }\end{array}$ & $\begin{array}{l}\text { American Public Health Association } \\
\text { (APHA, 2009) }\end{array}$ & $\begin{array}{l}\text { Number of active members in the } \\
\text { American Public Health } \\
\text { Association per hundred } \\
\text { thousand population }\end{array}$ \\
\hline Uninsured women & American Cancer Society & $\begin{array}{l}\text { Percentage of uninsured women in } \\
\text { each state }\end{array}$ \\
\hline Black population & United States Census Bureau (2010) & $\begin{array}{l}\text { Percentage of African American } \\
\text { population in } 2006\end{array}$ \\
\hline Latino population & United States Census Bureau (2010) & $\begin{array}{l}\text { Percentage of Latino population in } \\
2006\end{array}$ \\
\hline
\end{tabular}

